\title{
Sun protection and other uses of Thanakha in Myanmar
}

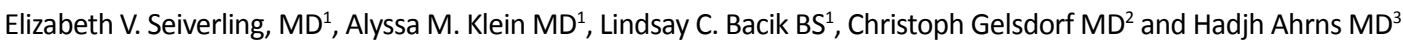

Seiverling EV, Klein AM, Bacik LC, et al. Sun protection and other uses of Thanakha in Myanmar. Curr Res Integr Med 2017;2(3): 26-27.

OBJECTIVES: Thanakha is a powder produced from the bark of Hesperethusa crenulata or Naringi crenulata trees, and has been used by Burmese people for over 2,000 years. The powder is traditionally mixed with water to form a thin yellow paste which is then applied directly to the skin. The purpose of this study was to determine the dermatologic uses of thanakha in Myanmar.

DESIGN: This cross-sectional study was conducted in Myanmar and consisted of 25 semi-structured interviews with Burmese people who wear thanakha. Participants were both men and women, ages 12-55, and represented three different regions of Myanmar.
RESULTS: Nine distinct dermatologic uses of thanakha were identified: photo-protection, acne treatment and prevention, skin lightening, skin cooling, beautification (make-up), rhytid (wrinkle) reduction, pruritus relief, scar reduction, and odor prevention. Of these, the most commonly reported reason for applying thanakha to the skin was sun protection.

CONCLUSION: Thanakha is being used daily for the treatment and prevention of some the most prevalent dermatologic conditions. As travel restrictions to Myanmar ease, further research should investigate the efficacy and safety of thanakha for various dermatologic conditions.

Key Words: Thanakha, Sun Protection, Myanmar
Tanakha powder, used by Burmese people, is produced from the bark of the Hesperethusa crenulata or Naringi crenulata trees (1). The powder is mixed with water to form a thin yellow paste, which is applied directly to the skin (Figure 1). The purpose of our research was to determine the dermatologic uses of thanakha in Myanmar.

\section{METHODS}

We conducted 25 semi-structured interviews and performed a summative content analysis of the responses. We coded and counted the frequency of keywords found in the interview responses. Participants were both men and women, ages 12 to 55, from different regions of Myanmar, and represented different ethnicities and religious groups.

\section{RESULTS}

Nine distinct dermatologic uses of thanakha were identified: photo-protection, acne treatment and prevention, skin lightening, skin cooling, beautification (make-up), rhytid (wrinkle) reduction, pruritus relief, scar reduction, and odor prevention (Table 1). Of these, the most commonly reported reason for applying thanakha was sun protection. All 25 participants stated this was a reason for daily morning application. Skin cooling, skin whitening, and acne treatment or prevention were the other most reported reasons for applying thanakha. The most important reason for applying thanakha was acne treatment and prevention in patients under 16 and sun protection in those 17 or older, followed by skin cooling and skin lightening. The additional dermatologic uses for thanakha (numbers 5 to 9 in table) were each reported by at least three study participants.

\section{DISCUSSION}

\section{TABLE 1}

\section{Dermatologic uses of thanakha}

\begin{tabular}{cc}
\hline $\begin{array}{c}\text { Reason for application } \\
\text { of thanakha }\end{array}$ & Number of responses \\
\hline Photo-Protection & 25 \\
Acne Treatment and & 10 \\
Prevention & 13 \\
Skin Lightening & 14 \\
Skin Cooling & 9 \\
Beautification (Make-Up) & 7 \\
Rhytid (Wrinkle) & 8 \\
Reduction & 3 \\
Pruritus Relief & 8 \\
Scar Reduction & \\
Odor Prevention &
\end{tabular}

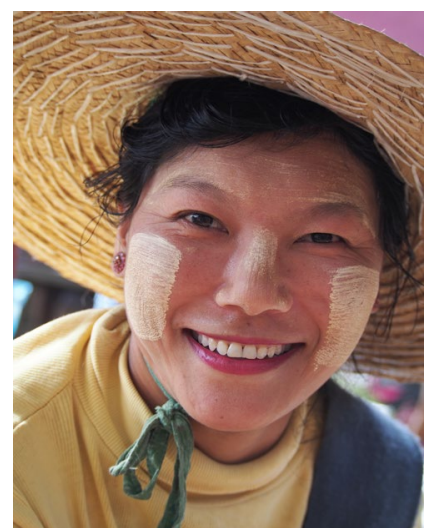

Figure 1) Thanakha for sun protection

Sun protection was the most commonly reported reason for applying thanakha. H. crenulata extracts contain marmesin (2). Marmesin, a fourocumarin (like psoralen) has a $\lambda_{\max }$ of $335 \mathrm{~nm}$ resulting in absorption of ultraviolet $\mathrm{A}$ radiation. When compared to titanium dioxide, marmesin has comparable efficacy in UVA absorption (2). In contrast to psoralens, the result of marmesin absorption of UVA is not mutagenic (3). Thus, the use of thanakha for sun protection and to reduce rhytids is supported by the presence of marmesin.

Among younger participants, acne treatment or prevention was the most commonly reported reason for applying thanakha. Wanthong et al. reported that thanakha bark has strong anti-inflammatory, significant antioxidant, and slight antibacterial properties (4). Thus, thanakha may impact two of the important etiologic pathways in acne pathogenesis-inflammation and bacterial overgrowth. A study to determine the effects of thanakha on Propionibacterium acnes is underway at our institution.

Skin cooling, whitening and beautification were additional reported reasons for application of thanakha. Thanakha contains menthol and alcohol, which contribute to its cooling properties. The skin lightening effects are related to arbutin, which inhibits melanin production by decreasing tyrosinase activity (4). When used as make-up, thanakha is commonly applied to the face as squares or circular patches on the cheeks.

Lastly, some participants reported use of thanakha for treatment of itchy

${ }^{1}$ Penn State College of Medicine. Department of Dermatology, ${ }^{2}$ University of California, San Francisco. Department of Family $\mathcal{E}$ Community Medicine, ${ }^{3}$ Penn State College of Medicine. Department of Family $\mathbb{E}$ Community Medicine

Correspondence: Elizabeth V. Seiverling MD, Penn State Hershey College of Medicine, 500 University Dr, UPC 1, Suite 100 Hershey, PA 17033, Telephone: (717) 5316820, Fax: (717) 531-4702, E-mail-eseiverling@pennstatehealth.psu.edu

Received: April 24, 2017, Accepted: May 22, 2017, Published: May 29, 2017

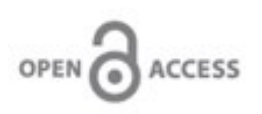

This open-access article is distributed under the terms of the Creative Commons Attribution Non-Commercial License (CC BY-NC) (http:// creativecommons.org/licenses/by-nc/4.0/), which permits reuse, distribution and reproduction of the article, provided that the original work is properly cited and the reuse is restricted to noncommercial purposes. For commercial reuse, contact reprints@pulsus.com 


\section{Seiverling et al}

rashes and for odor prevention. Thanakha may have anti-pruritic properties since it contains menthol, as is found in pramoxine and other anti-itch products. Anti-itch properties may also be due to the anti-inflammatory components akin to steroid creams. For odor prevention, thanakha is sometimes mixed with sandalwood, an aromatic plant derivative used in perfumes.

Our study did not seek to determine safety or efficacy of thanakha. Review of the literature found no reports of contact dermatitis due to thanakha. However, there are reports of thanakha products containing lead and being linked to elevated blood lead levels (5).

\section{CONCLUSION}

In conclusion, our study identified nine distinct dermatologic reasons Burmese people apply thanakha to their skin. Further research is needed to investigate the efficacy and safety of thanakha and to explore the role thanakha may have in photo-protection, acne treatment and prevention, treatment of hyperpigmentation, and in cosmetic skin regimens.

\section{DISCLOSURES}

No conflict of interest to disclose.

\section{REFERENCES}

1. Goldsberry A, Dinner A, Hanke CW. Thanaka: A traditional Burmese sun protection. Journal of Drugs in Dermatology: JDD. 2014;13(3):306-307.

2. Joo SH, Lee SC, Kim SK. UV absorbent, marmesin, from the bark of Thanakha, Hesperethusa crenulata L. Journal of Plant Biology. 2004;47(2):163-165.

3. US EPA. Linear and angular furomarins: Psoralens, angelicins, and related compounds: Carcinogenicity and structure activity relationships: Other biological properties, Metabolism: Environmental significance. National Service Center for Environmental Publications, Cincinnati, OH. PB560R860015, 1986.

4. Wangthong S, Palaga T, Rengpipat S, et al. Biological activities and safety of Thanaka (Hesperethusa crenulata) stem bark. Journal of Ethnopharmacology. 2010;132(2):466-472.

5. Ritchey MD, Scalia Sucosky M, Jefferies $T$, et al. Lead poisoning among Burmese refugee children-Indiana, 2009. Clinical Pediatrics. 2011;50(7):648-656. 